\title{
UNDERSTANDING OF GENETICALLY MODIFIED ORGANISMS
}

\section{Željko Kaluđerović ${ }^{1}$ Jovana Potpara}

Faculty of Philosophy, Novi Sad, Department of Philosophy
Review paper

Received: 21.03 .2012

UDC: $179: 631.528 .6$

Accepted: 30.06 .2012

\begin{abstract}
During the last sixteen years biotechnology, genetic engineering, transgenic organisms or genetically modified organisms (GMOs) have been raising numerous controversies. In the scientific sphere, genetic engineering and GMOs represent a special challenge for geneticists, breeders and physicians, in philosophy it is a topic of interest for bioethicists and agricultural ethicists, environmentalists are interested in the interconnectictions between new technology and environment protection, for multinational companies this is a potential source of huge profits, and for certain governments they represent an instrument for strategic control of food production within their countries as well as internationally. By taking into account the views of both advocates and opponents of this "revolutionary" method, authors believe that we should not a priori reject new and insufficiently studied technologies, but that in this particular it is necessary to be extremely cautious, in other words that from (bio)ethical point of view only those GMO investigations limited to scientific purposes are justified, provided that all required precautions have been taken. Also, authors are of the opinion that in this region as well as in Europe as a whole, at this moment, transgenic organisms are not necessery, neither in agricultural production nor in the food chain. Arguments for such a statement are found primarily in the potential issues that intentional breeding of GMOs might inflict upon the human health and environment. Namely, if borders of individual species are not overstepped and if their endogenous traits are made stronger, the potential risk of causing irreparable damage for both present and future generations which may be brought by changed biological succession will be reduced, i.e. one of the four fundamental bioethical principles will be applied and that is the nonmaleficence. Further intentional decreasing of biodiversity should not be allowed, which means that it is necessary to respect as much as it is possible the complexity of the very nature, its autonomy and "otherness".
\end{abstract}

Key words: GMOs, biotechnology, bioethics, "Gene Revolution", biodiversity, nature, "otherness", controversies.

Biotechnology, molecular genetics, genetic engineering, transgenes or genetically modified organisms (GMOs), represent methods, technologies and products that not only were shaking the scientific circles at the end of the previous century, and certainly will not remain an exclusive topic for narrow academic circles in the new millenium, but they will also become a subject of approval or rejoice for laymen.

${ }^{1}$ Correspodence to:

Željko Kaluđerović, PhD, Faculty of Philosophy, Novi Sad, Department of Philosophy

Dr Zorana Đinđića 2, 21000, Novi Sad, Serbia

Phone: +38121459279

E-mail: zeljko.kaludjerovic@gmail.com 
At the very beginning it is necessary to clarify the actual meaning of the key phrase of genetically modified organisms. The problem has occured due to its relatively frequent, differentiated and uncritical use, and also since the "self-explainatoriness" of a certain term is never sufficient and its commonality is never philosophically relevant, because it neither says much about the term itself nor facilitates its understanding. Genetic modification, in its broadest sense, implies any alteration in genes, potentially by recombination of inherited parent genes, and is obtained by combination of parent organisms, hybridization during the process of breeding and selection of organisms. Genome changes can be also changes in the number of chromozomes, or larger changes in genetic makeup, obtained by cytogenetics techniques. Genetic modification can occur at a gene level, or at the level of a smaller group of genes, by techniques of molecular genetics, i.e. genetic engineering. All organisms obtained in the above mentioned ways can be considered as genetically modified. So, by genetically modified organisms we mean organisms whose genetic makeup has been altered in ways not possible through traditional reproduction or through natural recombination of existing genes of the species. In other words, these genetically modified or transgenic organisms have had their genetic makeup modified in the way that could never have happened in nature. Gene constructions by which the host genome is modified most frequently originate from totally unrelated species, and thus the limits in the natural gene flow of changes of genetic information are either eliminated or moved ${ }^{2}$.

DNAs of genetically modified organisms contain genes introduced from a different species, or genes introduced by laboratory methods and techniques. Genetic material introduced into DNA of the host cell can be taken from plants, microorganisms, insects and animals, including humans, while so called synthtetic genes have been also mentioned recently.

\footnotetext{
${ }^{2}$ Over 3000 plants, animals and microorganisms have been developed in this way, mostly in laboratories in USA. However, only a little over 40 species of GM plant culture has been approved for marketing and a relatively small number of projects has been completely commercialized.
}

GMO proponents claim that GMOs have led to increased quality and fertility of agricultural crops, increase in the quality of food products (longer durability and better tolerance to transport conditions), as well as a better resistance of crops to disease, insects and weeds. It has been stated that GM technology is intended to widen the area of crop growing, improve the tolerability to low temperatures or draught and increase the exploitation of currently non-productive degraded soils by growing better adapted agricultural crops. The elements of the food produced in this manner would be of greater quality and enriched by essential amino-acids, mineral substances, vitamins and non-caloric sweeten$\mathrm{ers}^{3}$. The idea is that, for example genetically modified tomato and pepper will produce significant amounts of lycopene, which is a highly important anti-oxidant. The application of biotechnology has also increased the level of unsaturated fatty acids in canola, soybean, sunflower and peanuts, which increase biological and nutrient properties of oil. The carbohydrate content can be also modified by biotechnology and, as a result, tomatos with higher content of dry matter, more suitable for industrial processing have been created. Some tropical crops, such as bananas, are genetically modified to produce proteins which can be used as vaccines to prevent hepatitis, dysentery, cholera, diarrhea or other stomach infections characteristic for developing countries. The futuristic representation of genetically modified plants also suggests their medicinal properties, let's say of potato, banana and tomato, which could be modified to contain vaccines, while for example tea will become flavonoid-enriched.

\footnotetext{
${ }^{3}$ Desirable nutritional properties such as modified proteins or fat content are particularly significant, because, as it is generally held, for example, genetically modified rice containing more $\beta$-carotene and iron will contribute to resolving of the problem of their defficiency in the countries where rice is the major food source, which should directly contribute to the mitigation of the risks of blindness and anaemia. Unfortunately, although this seems to be a humane idea, the project of so called "golden rice" was demistified as far back as 2000 and, despite high investments, it has turned out to be a complete failure in resolving the mentioned problems (for more details see: Jošt \& Cox, 2003, pp. 93-102).
} 
The project of modifying plants to produce insuline has been started in order to enable insulin regulation through nutrition instead of by injections. Transgenic organisms are also supposed to, according to this optimistic projection, enable the production of cheaper medicines and organ transplants. By applying the new biotechnology, eventually, environment protection will be raised to a higher level by microbiological purification of polluted watercourses and waste waters and by decreased application of chemical substances in agriculture (herbicides and pesticides).

However, it needs to be said that at this moment majority of things related to so called the second and third generations of transgenic plants ${ }^{4}$ have not progressed much further from proclamations.

Their realization implies that first of all the transgenic technology needs to become widely accepted, which still is not the case. A particular problem is the fact that GMO promoters quite rarely mention, or even consciously avoid mentioning, the negative effects of these products.

\footnotetext{
${ }^{4}$ Generally, three generations of genetically modified plants can be distinguguished: the first generation has been known for a long time and consists of projects such as resistance to herbicides, viruses or insects. Recently, genetic modifications have become much more comlex, they imply introduction of a larger number of genes into the genome of the host plant, so called stacked properties (example is resistance of corn to corn borer and total herbicide). Simultaneosly there are attempts to change the number of existing metabolic paths in the plant, by deactivating the undesired and/or activating desired genes, therefore it is expected that this second generation of transgenic plants will be marked by genotypes with altered nutritional values. These so called output properties shall supposingly keep fruit and vegetables fresh longer, affect healthier fats and oils, increased nutritional value such as for example higner vitamine contents, creation of soybean with more anti-cancer proteins (genes found within the same genome) and a wide range of high value foods (for example high-lysine maize). The third generation, so called special properties, probably will represent plants that will be used for the needs of pharmaceutical industry as bioreactors or as an efficient metod of creating and using vaccines.
}

In this way the findings of experiments showing that GM food causes a potential risk to human health are minimized $^{5}$, harmful effect upon the environment or general deterioration of the quality of agricultural crops. The topic of endangering traditional agricultural production has also been neglected, by direct interventions of multinational companies when laws or directives are passed, whereby they undoubtfully demonostrate the corporate power of money, as well as classical dilemas related to the risk of irreparable damage upon present and future generations which can be inflicted by biological heritage. Authors of this paper are at the standing point that patenting living organisms by multinational companies is bioethically unacceptable and unjustly, not only because of monopolies in production and trade of GM plants, but also because of attempts to achieve domination over the life itself.

Introduction of GM agricultural crops into production and their influence upon biodiversity ${ }^{6}$, can be considered at least in two ways. It is a fact that new genetically engineered genotypes are to a certain extent also carrying new genetic diversity, but at the same time it is a fact that by introducing transgenic technology into agriculture the trend of endangering biodiversity started by intensifying agricultural production and "Green Revolution" is continued. By growing several GM crops in monoculture across large areas and by their spreading in developing countries, surpressing of local populations which small farmers are still growing in these countries is continued.

\footnotetext{
${ }^{5}$ The American company Pioneer Hi-bred International in order to increase the content of proteins introduced a gene from Brazil nut responsible for this property into soybean. Thus modified soybean was causing allergic reactions in people allergic to Brazil nut, so the project was soon withdrawn. Another example that led to identical consequences was transgenic tomato containing a fish gene, which has understandably caused problems to people who are allergic to fish.

${ }^{6}$ Biological diversity, or abbreviatedly biodiversity, implies variety, i.e. variability of plants, animals and other living organisms in a certain area. In other words, we are talking about the variety of species in a particular ecosystem. Biodiversity is a complex notion comprising not only variability, but also mutual influences (interaction) of organisms, both mutually and with the environment they live in, so it is not easy to define it unambigiouslly.
} 
GM agricultural crops exert a strong selective pressure on the insects feeding on them as well as on weeds, and quite often, in terms of a food chain, on non-targeted organisms but are feeding or parasite on organisms and are considered as pests in plant production. Therefore, they become target organisms of transgenic technology.

Spreading of the GM agricultural crops can indeed pose a threat to biodiversity, particularly at the centers of origin of agricultural plants, i.e. in those regions of the world where the specific species of important agricultural crops originate from. These centers of origin are also characterised by the highest genetic variability for those species and can be used as useful gene sources in spreading the genetic variability in conventional breeding. Due to transgression of genes from a GM crop to spontaneous (indigineous relatives) these natural resources of useful genes may be significantly endangered ${ }^{7}$.

Common reasons for questioning genetic modifications are connected to their opposition to nature, i.e. to the firmly expressed attitude that GM is something unnatural. From the bioethical point of view it seems that human intervention to an organism is not generally questionable, since controlled breeding is acceptable, unlike the intervention conducted at the level of DNA. The argument that genetic modification of an organism is impersmissible from the bioethical point of view since it is in opposition to the natural flow of things, i.e. because it is unnatural, should be additionally problematized. Namely, to (self)understanding of the essence of man belongs the feeling or image of a kind of the sundering of the direct i.e. natural existence of man, which makes man in its own perspective a unique event in the world, because his existence is represented to him as un-natural, artificial, modifiable, as second-nature or the highest point of the continuity of nature.

\footnotetext{
${ }^{7}$ The threat is even greater since GM seeds are brought illegally into many countries and often even the producers do not know what they are sawing. It is interesting that multinational companies, which are very consistent in the protection of their own property and patent rights, do not exhibit the same promptness and interest to protect their rights in the case of growing illegally imported GM seeds to certain countries, without a signed contract.
}

In other words, spiritual existence of man may be understood as the highest step of his natural existence (or nature in general), or as a walkaway from natural existence. Hence, to say that something is un-natural does not mean nor imply that it immanently bears a negative axiological sign. It is interesting that the argument of nature is also used by both the proponents and opponents of genetically modified organisms. Proponents believe that genetic modification is acceptable from the bioethical point of view, since unexpected and sudden changes in DNA do happen in the nature itself, just like the exchange of genetic material between species. GM opponents, on the other hand, use this fact to confirm that given phenomena are not common in nature, and thus they are not acceptable bioethically. The reasoning presented in both versions implies a common sense approach, which potentially may form the public opinion by understanding the natural as something "normal". However, it certainly must not determine the philosophical consideration of genetic modifications.

To proclaim something as "unnatural" in the specific case means that genetic material is being transfered accros the borders of certain species. Certainly, it is not possible to define a species once and for all and its concept may vary from one epoque to another and depend on the given context. In one sense "species" may indicate a group of individuals being similar in appearance and properties, while in the other it is related to individuals which belong to the same species when they can bear or produce fertile offspring. In plant life, further, it is not always possible to make a clear distinction between certain species. If we add to this their previous common origin, there is a reason why some authors, based on the statement that species have changed their characteristics during the evolution process, have indicated the fact that telos species is not a static but dynamic category. 
Ecological system represents a fragile state of constant changes, a so to say dynamic equilibrium, which is changing, although at the same tam it retains the basic traits over time ${ }^{8}$. Despite the rapid increase of the quantum of knowledge in recent decades, due to the complexity of the ecosystem, the scientists are not in a position to completely estimate the consequences even of highly limited changes. The science still lacks sufficient understanding of how biological systems function, in contrast to the system that men have constructed themselves, where the causes are well known, and the consequences of changes upon the system itself can be foreseen up to the smallest detail. In this sense, the nature is not something that can be completely controlled and which can be easily managed. In this way the laws of biology uncover the "otherness" i.e. "difference" of nature. Biological systems therefore at this moment cannot be completely predictable, so when the biotechnology intervenes into them it makes a kind of a shortcut, as compared to the ways in which the changes usually occur in nature. Transgenic crops radically change the characteristics which were introduced simultaneously into a wide range of coverage, by which unique peculiarity of these systems is not taken into consideration at all and thus the power of the technology itself is being overemphasized. This could be an adequate interpretation of objections that the man "is playing God", thus making the products of modern biotechnology "unnatural". Naturally, rigidly implemented this approach may imply rejection of any kind of modern biotechnology, while if led to absurdity this attitude may imply that we should abandon the postulates of modern agriculture in general, which certainly is not an intention of authors of this paper.

\footnotetext{
${ }^{8}$ This wording is close to Aristotle's definition of substance from Metaphysics 983b6-18, which is defined as something that is everlasting in intself while it is changing in its properties (pathos). Strictly speaking, Stagirites does not say that the properties are changing, but that the substance is changed through them, whereas it remains unchanged. Permanence or stability in its own nature while undergoing changes is a characteristic of the substance which is always emphasised. In a similar way it could be said that an ecosystem remains unchanged in its substance, while at the same time it undergoes uncountable modifications.
}

The natural selection process, which represents a basic mechanism of change inducing in nature, is quite a slow process. Respecting the fact that the science can not explain all details of the interaction of elements in nature, it is necessary to respect restrictions regarding the rate and dispersion of changes in nature in the way they have been expressed in changes caused by evolution. If evolution constraints of genetic changes have been taken into consideration, products of human intervention will be more predictable because thus experimenting with the unknown in the complete sense of the word is slowed down. The option of avoiding any kind of intervention at the level of DNA $i$ application of knowledge which is also rapidly developing in the field of functional genomics which is an area of molecular biology, in order to advance the process of breed is possible and valid ${ }^{9}$. The other option advocates the constrating of the level of changes being introduced by means of genetic modification, at the same time maintainging the advantages of this technology. Intragenic modification can be determined as a genetic modification by means of reproductive DNA technology to produce an organism which could have been also obtained by traditional breeding measures. It is also well known that intragenic modification in some cases may result in changes which are not possible by traditional breeding. In such cases objections can be identical as in the situation of "unnatural" intervention in transgenic plants. Moreover, such plants should not be even called intragenic plants, despite the fact they were produced in a similar way.

\footnotetext{
${ }^{9}$ Multinational chemical companies which were exponents and financiers of transgenic projects have predominantly taken car how to facilitate the production process for the farmers, i.e. how to make this process safer and more profitable, and then, or in the first place, how to capitalise on investment in such projects as quickly as possible. In this way transgenic programs with herbicide resistance genes were forced despite the fact that for example for corn there is a whole range of herbicieds of high quality. Theoretically it is, of course, possible to create plants tolerant to almost all herbicides, although commerical application have only economically more important plant cultivars and herbicides of favorable properties (glyphosate, gluphosinate ammonium, imidazolinon herbicides, sulphonylurea herbicides, cyclo-hexandions, bromoxynil, etc).
} 
These plants are functionally similar to transgenic plants, and the accent in differentiation between intragenic and transgenic modifications should be placed onto the novelty of properties, and not on the origin of genetic material.

The key element of this argument is not primarily the avoidance of unexpectable damage, but the respect of "otherness" of nature. If anywhere the lesson of helenic understanding of hybris can be applied then it maybe should be appled in wantonness of the man towards "otherness" of nature and subsequent consequences for its disregard. By remaining within the borders of a species in contemporary scientific research, and also during genetic modifications, the man accelerates the process of changes in accordance with their own requests, and simultaneously demonstrating the respect for these borders set by the evolution process. Such an act also demonstrates the respect of basic postulates of bioethics set by J. F. Childress and T. L. Beauchamp, such as nonmaleficence and autonomy, and also even justice and beneficence.

\section{REFERENCES}

Abdalla, A., Berry, P., Connell, P., Tran, Q. T., Buetre, B. (2003). Agricultural Biotechnology, Canberra.

Aristotel. (2007). Metafizika. Searbia, Beograd. PAIDEIA. Beauchamp, T. L. and Childress, J. F. (1994). Principles of Biomedical Ethics, Oxford.

Domingo, J. L. (2000) Health risk of GM food - Many options but few data, Science, vol. 288.

Freudenberger, C. D. (1994). What is good agriculture? Agricultural Ethics: Issues for the 21st century, ASA, Special publication, No. 57.

Jackson, W. (1985). New Roots for Agriculture, Lincoln and London.

Jošt, M. and CoxX, T. (2003). Intelektualni izazov tehnologije samouništenja. Croatia, Križevci. Ogr. Mat. hrvatske.

Kaluđerović, Ž. (2009). Kontroverze oko GM ili transgenih organizama. ARHE, god. VI, br. 12, Novi Sad.

Krznar, T. (2009). Bioetički mozaik. Croatia, Karlovac, Veleučilište u Karlovcu.

Littlehales, C. and Massey, A. (2007). Guide to Biotechnology, Washington.

Reich, W. T. (1995). Encyclopedia of Bioethics, Simon \& Schuster - Macmillan, New York, 1995.

Sober, E. (2006). Filozofija biologije, Beograd, П $\Lambda$ AT $\Omega$.

Vrček, V. (2010). GMO između prisile $i$ otpora. Croatia, Zagreb, PERGAMENA. 